\title{
THE ROLE OF SEASON AND SALINITY IN INFLUENCING BARNACLE DISTRIBUTIONS IN TWO ADJACENT COASTAL MANGROVE LAGOONS
}

\author{
Victoria Starczak, Paula Pérez-Brunius, \\ Hazel E Levine, Joanna Gyory, and Jesús Pineda
}

\begin{abstract}
Barnacles are often abundant on roots and branches of mangrove trees in tidal channels and coastal lagoons of the Pacific coast of Panama. Yet, in some coastal lagoons, barnacles are absent. We investigated pre- and post-settlement factors that affect barnacle distributions in two adjacent coastal lagoons in Bahía Honda, Panama, one with moderate to large barnacle populations, and the other with nearly non-existent populations. Although mean barnacle recruitment was higher on mangrove root segments during the dry season (December-April) than in the wet season (May-November), it was not significantly different between the two coastal lagoons. The coastal lagoon with fewer barnacles is considered an estuary, with high freshwater flow and low salinities (0.1) during the wet season that were lethal to barnacle nauplii and cyprids. Furthermore, coastal water was not observed to enter the lagoon, even during flood tides. In contrast, more barnacles were found in the lagoon with higher salinities (8.5). During the dry season, freshwater flow was greatly reduced in both lagoons, resulting in a similar salinity range (22-33). We conclude that the lack of barnacles in the estuarine coastal lagoon is largely due to high flushing rates and low salinities that reduce larval concentrations during the wet season. Moreover, low adult abundance in the lagoon's interior may further reduce larval supply and settlement.
\end{abstract}

Population and community dynamics of nearshore species with a two-phase life cycle are determined by (1) pre-settlement processes, which affect the abundance of larvae, their delivery to adult habitats, and their settlement, and (2) post-settlement processes impacting juveniles and adults. Larval development may influence settlement and recruitment (Thiyagarajan et al. 2002, Jarrett 2003, Giménez 2004, Sponaugle et al. 2006), and larval behavior at settlement can have a key role in recruitment (Blythe and Pineda 2009). A long-standing research topic in marine ecology is the relative importance of these processes in determining population and community dynamics (Hatton 1938, Connell 1985). Larval supply to adult habitats, or its operational equivalent, larval abundance near settlement sites, is influenced by factors affecting larval pool size, transport, and behavior (Connell 1985, Pineda 2000). Researchers investigating larval pool size have focused on predation as the most important mortality factor (e.g., Morgan 1995). Natural stressors (e.g., changes in temperature or salinity) causing larval mortality can also affect nearshore larval abundance, and temporal and spatial variability in stressors may generate spatial patterns in populations and communities. In general, natural stressors have received less attention than predation and competition in regulating hard-substrate benthic communities. 
Our study was based in the coastal lagoons of Bahía Honda, a bay on the Pacific coast of Panama located within the biogeographic region of Nicoya (Spalding et al. 2007). The seasons in Panama are largely characterized by the amount of rainfall, with the tropical mangroves of the Nicoya region receiving some of the highest yearly rainfall in the Americas. During the rainy season (between May and November, approximately), the total precipitation averages $2000-3000 \mathrm{~mm}$, whereas precipitation during the dry season (December-April) averages 300-900 mm [data from meteorological stations in Veraguas Province, Panama, provided by Gerencia de Hidrometeorología, Empresa de Transmisión Eléctrica, SA, and from the National Centers for Environmental Prediction (NCEP)/National Center of Atmospheric Research (NCAR) Reanalysis Monthly Means and Other Derived Variables dataset, see also Kalnay et al. 1996].

The coastal lagoons and tidal channels of Panama are fringed by mangrove forests that grow at the interface between land and sea (Ellison 2004). Hence, tropical mangroves occupy similar intertidal habitats that marshes do in temperate environments, often growing on soft bottoms protected from the open ocean surf. Mangrove trees grow at the edges of these shallow channels and tidal flats, and produce aerial prop roots that form dense networks. Distributions of mangrove species within lagoons are determined by rainfall, salinity, exposure to wave action, and tides (West 1956, Duke et al. 1998, Karuppaiyan and Raja 2007), and the dominant mangrove species vary among lagoons. Mangrove trunks, branches, and roots are often the only hard substrate available for colonization by sessile and sedentary taxa (Bingham 1992, Farnsworth and Ellison 1996, Ross and Underwood 1997). The distribution of invertebrate fauna living on mangrove roots, epibionts, is partly determined by water flow and distance from the source population (Bingham 1992).

Water flow in estuaries with mangroves differs from flow in non-mangrove estuaries. Flows in mangrove laden estuaries experience greater drag from inundated roots and trees, and often the flow has larger eddy viscosity from turbulence generated around prop roots, pneumatophores, dense vegetation, and uneven mud flats (Ong et al. 1991, Mazda et al. 1997). As a result, while tidal flow in the lagoon's tidal channels is along-channel, flow in the inundated mangrove forest (hereafter referred as swamp) is bidimensional, parallel and perpendicular to tidal channels, and significantly slower (Kobashi and Mazda 2005). The bidimensional circulation within swamps is due to a component of the flow perpendicular to the channel, driven by a pressure gradient that results from the phase difference in sea level between the channel and the swamp (Mazda et al. 2007). Hence, the filling and emptying of the swamp is out of phase with the tidal flow in the lagoon tidal channels, and the lag depends on the density and species of the mangrove vegetation and the extension of the inundated area of the mangrove forest (Mazda et al. 1995). In the absence of river flow, temporary trapping of lagoon water in the swamp at each rising tide (Wolanski and Ridd 1986), and its subsequent release at a different phase of the ebb flow in the lagoon, can help retain passive tracers in the system. This trapping mechanism is responsible for retention of prawn larvae in straits fringed by Malaysian mangroves (Chong et al. 1996).

Given that mangrove coastal lagoons can retain larvae, it was surprising that our early (2001 and 2004) surveys in Bahía Honda mangroves revealed null to moderate densities of sessile intertidal epibionts (J Pineda, pers obs). In general, invertebrate density and biomass in Bahía Honda's mangrove roots are strikingly low compared 
to some other Pacific and Caribbean tropical and subtropical systems (J Pineda, pers obs). Moreover, various species of barnacles, mussels, and oysters occur at moderate to low densities in some coastal lagoon mangrove systems, but are absent in others.

The present study addresses the ecological effects (i.e., spatial and temporal patterns in mortality and survival) of natural stressors on larvae and recruits of barnacles in mangrove forests in southwestern Panama. It examines pre- and post-settlement factors that may explain why epibiont communities are present in some mangrove systems (e.g., La Isleta, a coastal lagoon with no river input), but are rare or absent in others (e.g., Managua, an estuarine coastal lagoon). We investigated possible causes for the difference between the two coastal lagoons, namely that: (1) differences in flushing influence larval supply and retention. Is larval retention, as inferred from flushing, higher in La Isleta than Managua? (2) differences in salinity, especially during the rainy season, may influence survival of larvae and settlers. Low salinity in estuarine Managua may result in the following: (a) planktonic larvae do not survive, (b) larvae survive but do not settle, or (c) larvae settle but are not able to survive in Managua; and (3) differences in settlement related to substrate composition. Larvae may settle at different rates among mangrove species; hence, differences in mangrove community structure may result in settlement variability. We investigated these possible differences by conducting field and laboratory experiments during two rainy seasons and one dry season. Our experiments focused on barnacles, because they are the most abundant invertebrate epibionts on the mangrove roots, and their larvae are naturally abundant in the plankton.

\section{Methods}

\section{Study Sites}

The two mangrove coastal lagoons are located in Bahía Honda, on the southwestern Pacific coast of Panama $\left(\sim 7^{\circ} 45.2^{\prime} \mathrm{N}, 81^{\circ} 29.6^{\prime} \mathrm{W}\right.$; Fig. 1$)$. We use "coastal lagoons" as a general term to describe these bodies of water, without implications for size and geomorphology (e.g., Phleger 1969). Managua is an estuarine coastal lagoon, while La Isleta is not river fed. The two systems are $1.3 \mathrm{~km}$ apart (mouth-to-mouth) and separated by a small cape. Each lagoon connects to Bahía Honda through a single mouth that is $20-30 \mathrm{~m}$ wide. The lagoons run parallel and perpendicular to the coastline with several bends. Each channel narrows with distance from the mouth and extends $\sim 500 \mathrm{~m}$ inland, with depths that range from 0 to $\sim 2.5 \mathrm{~m}$ within a tidal cycle. Side-channel swamps are inundated during most high tides and drain during low tides.

Three species of mangroves predominate in these two bodies of water: Rhizophora mangle Linnaeus and Pelliciera rhizophorae (Triana \& Planchon) are present in both systems, and Avicennia germinans (Linnaeus) Linnaeus is more abundant in Managua than La Isleta. Hills surround both lagoons, and mangrove forests extend along the tidal channels, which are sand and mud. Three common species of barnacles settle on Bahía Honda mangroves, Chthamalus spp., Amphibalanus inexpectatus (Pilsbry, 1916), and the higher intertidal and more abundant barnacle epibiont, Microeuraphia spp.

Physical measurements and biological experiments were conducted during three field trips that occurred during two rainy seasons (November 2005 and 2006) and one dry season (March 2006).

\section{Physical Measurements}

A goal of understanding settlement and recruitment is to understand how larvae arrive at locations to settle. Knowledge of the physical processes that can affect larval transport and physiological condition is critical to determining where larvae settle. To this end, physical measurements at the two coastal lagoons were designed to compare flushing and larval 

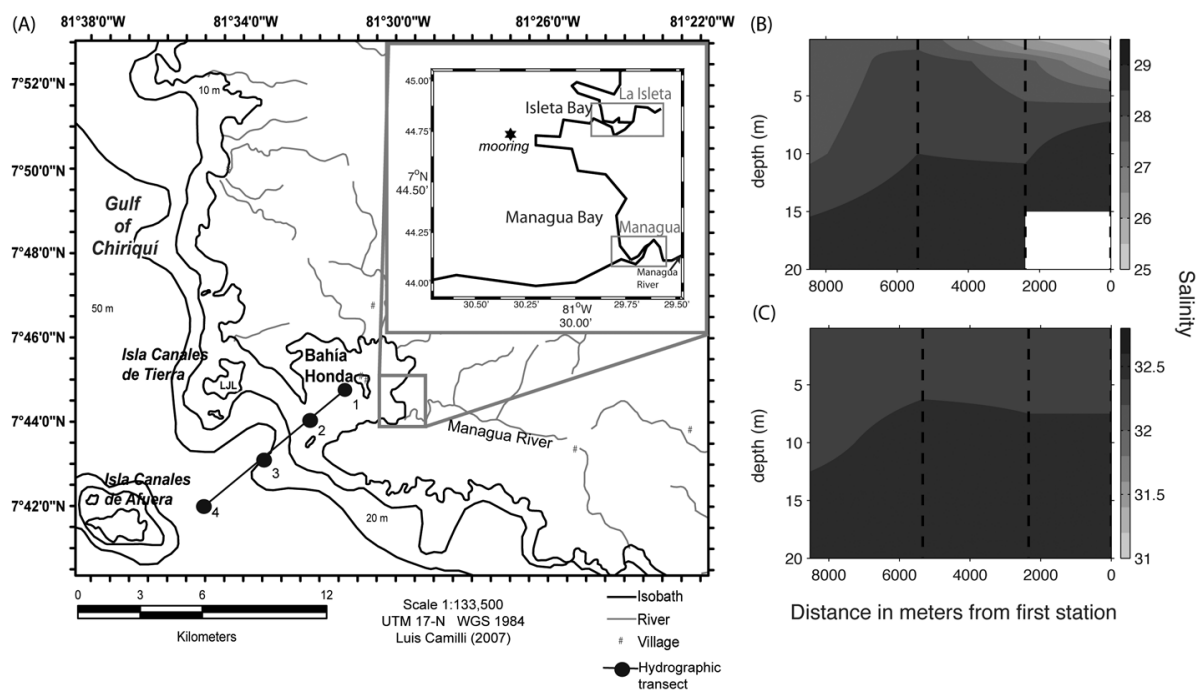

Distance in meters from first station

Figure 1. (A) Map of Bahía Honda, on the Pacific coast of Panama (adapted from Camilli 2007). Black points show positions of the hydrographic stations along the offshore transect (black line). The study region is enlarged in the top right corner and has the mooring (star) and the mangrove systems indicated (gray boxes). Offshore salinity transect in the (B) rainy season (1 December, 2005), and (C) dry season (30 March, 2006).

dispersion, assuming these processes are influenced by a combination of tidal currents and freshwater runoff.

Tides.-Simultaneous current and sea-level measurements were taken during each of the three field trips to determine the phase lag between high (low) tides and the onset of ebb (flood) currents, since they are not necessarily in phase in a semi-enclosed system like Bahía Honda. The water level in both mangrove systems is generally $<2.5 \mathrm{~m}$; and during low tide, large sections drain completely in the coastal lagoons and their adjacent bays. The onset of ebb and flood occurs simultaneously in both coastal lagoons because of their close proximity. Hence, ebb and flood currents were measured using a single mooring $\left(7^{\circ} 44.76^{\prime} \mathrm{N}, 81^{\circ} 30.3^{\prime} \mathrm{W}\right)$ located in deeper waters $(2-6 \mathrm{~m})$ between the entrance of the two coastal lagoons. On each of the three field trips, the mooring measured currents with an upward-facing Doppler current profiler (RDI ADCP Workhorse Sentinel, $1200 \mathrm{kHz}$ ), and bottom pressure for sea level with an SBE39 attached to the tripod housing the ADCP (Fig. 1). Record length was $6.3 \mathrm{~d}$ in March 2005, 11.8 d in November-December 2005, and 9 d in March 2006. Accuracy of the velocity measurements was $\pm 14 \mathrm{~mm} \mathrm{~s}^{-1}$.

During the third deployment (March 2006), vandals tipped the current meter tripod on the fifth day of sampling, so only data prior to day five were analyzed. Pressure data were recovered and corrected using the measured level of the sensor above the bottom before and after the vandalism. Thus, for the third deployment, the sea-level time series record is $9 \mathrm{~d}$ long, and harmonic analysis was used to extrapolate the record and partially predict the onset of ebb and flood during the missing ADCP data.

Currents were generally coherent with depth, with a decline in magnitude towards the bottom due to friction, and some occasional flow reversals toward the surface. Given that we were interested in estimating the magnitude and timing of the tidal ebb and flood flows, vertical averages of the current components were good approximations of water column movement and current magnitude.

Drifters.-Surface drifter experiments were conducted to estimate larval dispersion and water exchange (flushing) between the coastal lagoons and adjacent bodies of water (see Tapia 
et al. 2004 for drifter description). Sets of five drifters were deployed in the bays adjacent to the coastal lagoons at different stages of the tidal cycle. During both the dry and rainy season, drifters were followed and their locations recorded approximately every $10 \mathrm{~min}$ with GPS. Error in location measurement was $\sim 2-8 \mathrm{~m}$. Experiments lasted between $30 \mathrm{~min}$ and $4 \mathrm{hrs}$, and ended when more than three drifters reached land or drifted outside the corresponding bay. When this happened, the five drifters were redeployed. In November 2005, a small outboard motor boat was used to track drifter location between both bays. In March and November 2006, we followed drifters in La Isleta bay in a kayak and with a small outboard motor boat in Managua bay, enabling GPS measurements at intervals $<10 \mathrm{~min}$. Eleven experiments took place in Managua and 16 in La Isleta during ebb tide, while there were nine experiments in Managua and 14 in La Isleta during flood tide. Of these, eight experiments occurred simultaneously in both bays during ebb tide and seven experiments occurred during flood tide.

Drifter dispersion was calculated as the distance from deployment site to drifter location $50 \mathrm{~min}$ after deployment. We chose $50 \mathrm{~min}$ as the cutoff because longer intervals resulted in too many drifters stranded on shore. Data from 69 to 70 drifters from all deployments during the three field trips were used to estimate dispersion.

Salinity.-To determine whether the flows observed within and adjacent to the mangrove systems were influenced by freshwater runoff, salinity measurements were made during the second and third field trips. Measurements were taken along transects in both lagoons during neap tides in the rainy season (24 November, 2005, at the end of flood) and the dry season (27 March, 2006, near peak flood) using a Wildco Fieldmaster water sampler and a handheld conductivity and temperature meter (YSI model 30; Fig. 2A,B). Transects were sampled at or past peak flood tide to compare the influence of oceanic vs riverine water inside the two lagoons. To measure the influence of oceanic water in Bahía Honda, the effects of fresh water delivered offshore by direct precipitation and land runoff during the rainy season, salinity measurements down to $20 \mathrm{~m}$ depth were made along two transects that ran from the interior of Bahía Honda towards the open ocean. For details on physical data collection and analysis, see Pérez-Brunius et al. (2006).

\section{Biological Measurements}

Bioassay Larval Experiments.-Lack of barnacles inside Managua may be due to high larval mortality in the lagoon. Bioassay experiments were conducted to determine whether barnacle nauplius larvae could survive in water from four different sources: (1) offshore, (2) nearshore, (3) Managua, and (4) La Isleta. We collected larvae from two locations to determine whether larvae in more saline, offshore waters were more sensitive to the low salinity in the lagoons than were larvae collected near the lagoons.

Barnacle nauplius and cypris larvae for bioassays were collected with plankton nets (200 $\mu \mathrm{m}$ mesh) at two locations: $\sim 1 \mathrm{~km}$ from the mouths of La Isleta and Managua (nearshore) and $\sim 7 \mathrm{~km}$ outside of Bahía Honda (offshore). Larvae were not identified to species, but morphological differences in our collected cyprids indicated a mixed assemblage. Due to their numerical predominance and the similarity of cyprids collected in the plankton and on settlement plates near resident populations, we speculate that larvae in experiments included the abundant Microeuraphia spp., and also Chthamalus spp. and A. inexpectatus. Seawater for the experiments was collected from each location at the time of plankton sampling and from within each lagoon in the same day. In the lab, water was filtered $(0.47 \mu \mathrm{m})$ and salinity was measured with the conductivity-temperature meter. For each water treatment (Managua, La Isleta, nearshore, and offshore) in each experiment, five replicate, 50-ml glass beakers were filled with $40 \mathrm{ml}$ of filtered seawater. The number of larvae in each beaker differed between experiments and was dependent on the number of larvae collected (Table 1). In November 2005, Experiment 1, too few cypris larvae were collected; therefore, we used nauplii, collected nearshore and offshore. Experiment 2 was conducted with nearshore nauplii and no offshore water treatment. In March 2006, offshore and nearshore cyprids were used in Experiment 3, and Experiment 4 was performed with offshore cyprids and nauplii. Thus, collection area for 


\section{La Isleta}

(A)

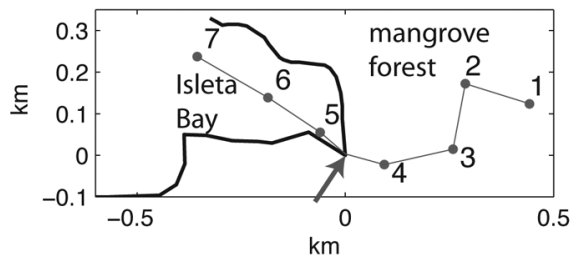

(C)

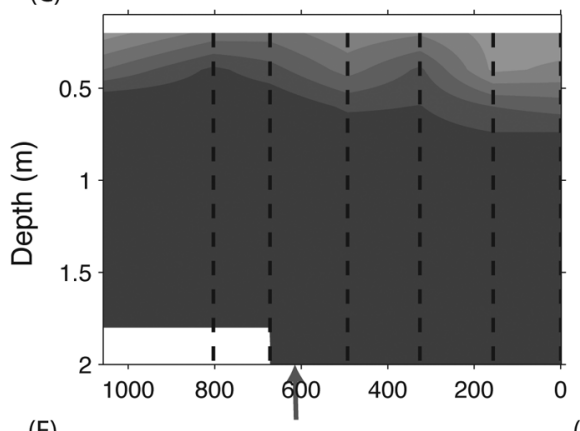

(E)

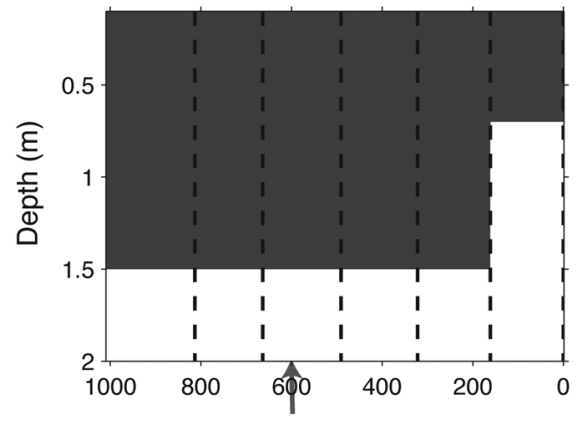

Managua

(B)
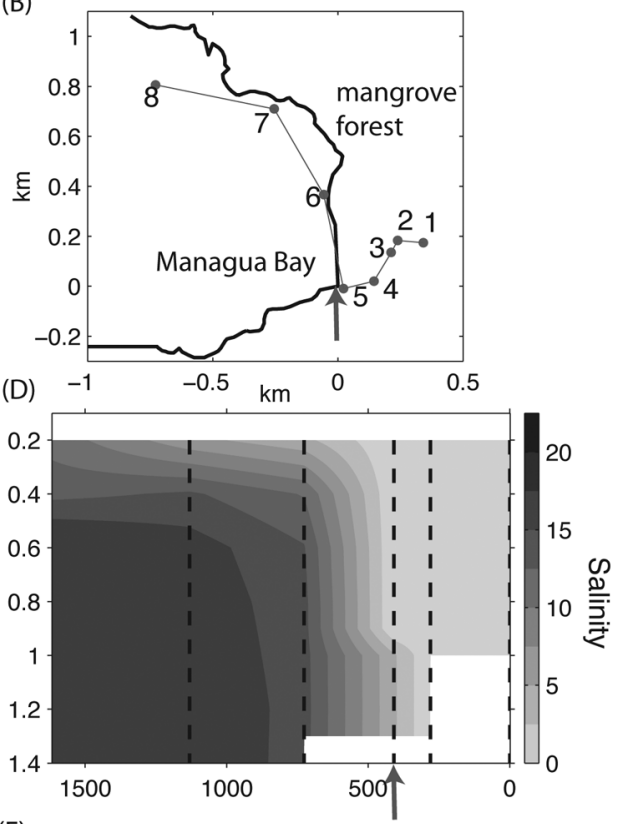

(F)

\section{Distance from first station $(\mathrm{m})$}

Figure 2. Salinity transects along the two mangrove coastal lagoon systems mark axis of lagoon channels. Left panels: La Isleta, right panels: Managua. Station positions for each transect are shown in (A) and (B). Salinity transects sampled during the rainy season (24 November, 2005, end of flood, neap tides, salinity range 0-27) at (C) La Isleta and (D) Managua. Salinity transects sampled during the dry season (27 March, 2006, mid-flood, a couple of days after neap tides, salinity range 21-28) at (E) La Isleta and (F) Managua. Coastal lagoon entrances are indicated by an arrow on the x-axis.

larvae was a separate treatment in Experiments 1 and 3, whereas larval type was a separate treatment in Experiment 4. In each experiment, larvae were added to randomized beakers within a treatment, and the state of each larva as (a) live, (b) dead, or (c) metamorphosed, was assessed after at least $18 \mathrm{hrs}$ (Table 1). To reduce the possible effects of variable food quality among treatments and experiments, no food was added during the experimental trials.

To test whether mortality differed between nearshore and offshore larvae, and among the four water treatments for Experiments 1 and 3, a two-way ANOVA was performed with the 


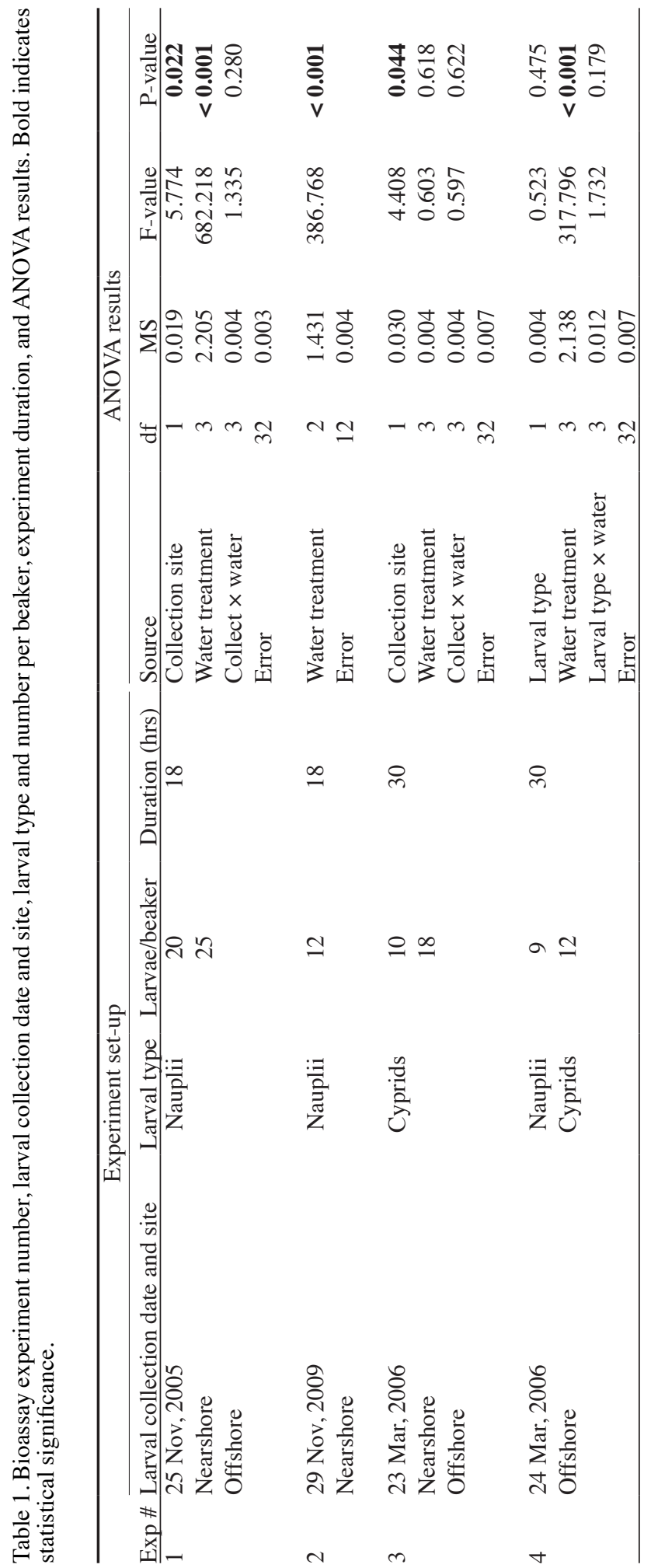


proportion of dead larvae out of the total larvae in each beaker as the dependent variable. In Experiment 4, a two-way ANOVA was used to compare mortality in cyprids and nauplii in the four water treatments. Finally, in Experiment 2, a one-way ANOVA was used to test whether nauplii collected from the nearshore differed in their mortality rate among the three water treatments. If water treatment was a significant main effect in any ANOVA model, pairwise mean differences in the water treatments were tested with a Tukey-Kramer test.

Larval Settlement.-To determine whether barnacle settlement was greater in La Isleta than Managua during the rainy and dry seasons, two types of settlement substrates were attached to living mangrove roots at various locations inside both lagoons in both seasons. The substrates were (1) segments of $R$. mangle roots with 20 (November 2005) or 25 (March 2006) small barnacles on them, and (2) PVC grooved plates $0.11 \mathrm{~m}$ long and $0.05 \mathrm{~m}$ wide (see Pineda 1994 for a description of the plates), with and without cages (plastic square mesh, 6 $\mathrm{mm}$ internal mesh width). Plates were caged or not caged to examine whether exclusion from predation affected settlement in either lagoon. Single plates (caged and uncaged) and roots (no cages) were deployed in seven (November 2005) or eight sites (March 2006) within the lagoons that ranged in location from near the entrance of each lagoon to $\sim 350 \mathrm{~m}$ within each lagoon. Plates and roots were collected after 5 (La Isleta) or $6 \mathrm{~d}$ (Managua) in November 2005 and after $7 \mathrm{~d}$ in March 2006. Logistical limitations determined sampling periods. Settled barnacles were counted under a dissecting microscope in the lab; newly settled barnacles could be distinguished by their small size from the larger, original barnacles. Settled barnacles included Microeuraphia spp., Chthamalus spp., and A. inexpectatus. Root segment length and width varied slightly, but mean surface area of root segments between treatments was not significantly different (results not shown).

Survival.-Survival of small barnacles (Microeuraphia spp. and Chthamalus spp.) was determined in both seasons by deploying root segments (as described above) with 20 barnacles at sites within each lagoon in November 2005. In March 2006, root segments had 25 barnacles to better estimate survival. After 5 or $7 \mathrm{~d}$, the newly settled barnacles (see above) and the barnacles originally deployed on the roots were enumerated with the aid of a dissecting scope.

Recruitment.-In both seasons, barnacle recruitment, defined as barnacle settlement and survival until substrate recovery, was assessed on (1) PVC plates, caged and uncaged, and on (2) segments of three species of mangroves ( $R$. mangle, A. germinans, and $P$. rhizophorae) that were devoid of barnacles. To assess a possible effect of predation on plates, caged and uncaged plates were deployed during two rainy seasons (11-12 March, 2005, until 28-29 November, 2005, and from 1 April, 2006, until 15 November, 2006) and in the dry season (30 November, 2005, until 22 March, 2006). Mangrove segments devoid of barnacles were not deployed during the first rainy season. After substrates were recovered, they were returned to the lab, and live barnacles (Chthamalus spp., Microeuraphia spp., and A. inexpectatus) were counted with the aid of a dissecting microscope.

For each season and each substrate, partial hierarchical ANOVAs (Brownlee 1965) were used to test whether the mean number of recruits on the substrate differed between lagoons or whether recruitment varied with location within a lagoon. For caged and uncaged plates, the dependent variable was number of live barnacles, and main (fixed) effects were Deployment, Lagoon, and Cage, with Location a random effect nested within Lagoon. No replicate plates or roots were deployed at any location in any lagoon. Therefore, the analysis assumes that the Cage $\times$ Location (Lagoon) interaction is not significant. Barnacle data were $\ln (x+1)$ transformed to homogenize variances. The same model was used to test for differences in recruitment between the three types of mangrove roots, with Root type as a factor in place of Cage.

Population Persistence.-Sessile invertebrate population persistence has two components: survival of established individuals and recruitment of new members. To measure population persistence throughout a season, segments of $R$. mangle roots with barnacles (Microeuraphia 


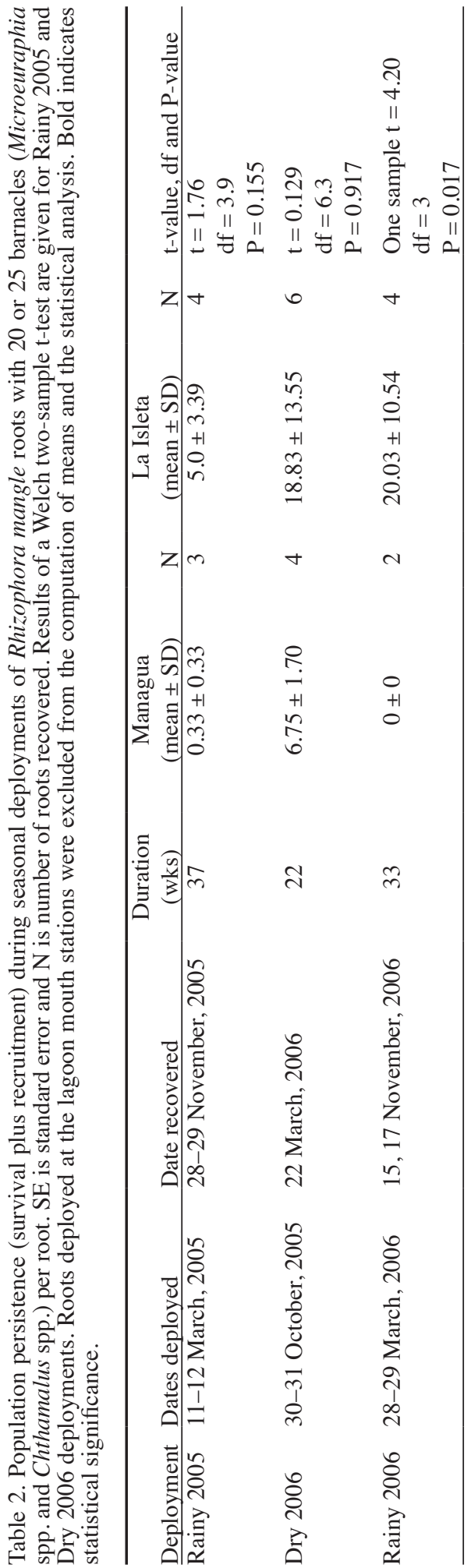


spp. and Chthamalus spp.) were attached to mangrove roots in locations along Isleta and Managua channels, and collected 5-8 mo later (Table 2). For the first experiment, Rainy 2005, nine roots were collected and all but 25 small barnacles were removed from each root. Four of these roots were affixed to $R$. mangle roots in four locations extending from the mouth to the interior of Managua, and five roots were affixed to five locations extending from the mouth to the interior of La Isleta. For the subsequent experiments, Dry 2006 and Rainy 2006, eight roots with 20 small barnacles each were deployed in each coastal lagoon eight locations extending from the mouth to the interior of the lagoon. At the end of the deployment, recovered roots were returned to the lab, and live barnacles were counted with the aid of a stereo microscope. Differentiation of original barnacles and recent recruits was not feasible. For each experiment, we tested whether mean number of live barnacles differed between the two lagoons with a two-sample Welch's t-test after excluding roots that were deployed at the mouths of each lagoon. Roots at the mouth locations had orders of magnitude more barnacles settle on them and do not reflect settlement within the rest of the lagoon. To homogenize variances, data were $\ln (x+1)$-transformed prior to analysis.

\section{Results}

\section{Physical Measurements}

Tides.- Sea level measured at the mooring showed a semidiurnal variation modulated by the spring-to-neap tidal cycle. Tidal range in Bahía Honda varied between $1.5 \mathrm{~m}$ (neap tides) and $3.5 \mathrm{~m}$ (spring tides).

The entrances of La Isleta and Managua face west; hence, the eastward component of the vertically averaged velocity was used to obtain the timing of the ebb and flood currents in the bays adjacent to the coastal lagoons. A harmonic analysis fit using the first two tidal components represented well the vertically averaged eastward component, explaining 91\% (March 2005), 73\% (November 2005), and 88\% (March 2006) of the velocity variance. Cross-correlation between sea level and the vertically averaged eastward velocity showed that maximum flood (ebb) currents precede the high (low) tide by $2-3$ hrs, so the tide in Bahía Honda behaves as a standing wave, i.e., maximum speeds are out of phase by $90^{\circ}$ with the maximum/minimum sea level. The timing of flood and ebb flows provided the framework to analyze the drifter and salinity measurements to address flushing and freshwater runoff in the coastal lagoons.

Flushing and Freshwater Input.-Salinity transect measurements collected during two expeditions suggest that, during the rainy season, Managua behaved as a river with very strong flow. Our few observations in the rainy season indicate that, during flood tide, water of oceanic character rarely entered the coastal lagoon (note that salinity measurements along transects were made during neap tides; Fig. 2C,D). However, river flow during the dry season was weak, with oceanic water entering far up into the coastal lagoon. La Isleta, on the other hand, exhibited non-estuarine coastal lagoon characteristics during both seasons, although salinities were low inside and outside the lagoon during the rainy season. These results were consistent with the drifter data (Fig. 3A,B). In general, drifters moved toward the mouths of the coastal lagoons during flood tide in the dry seasons. However, drifters moved away from the entrance of Managua in the rainy season, contrary to the direction expected during flood tide.

During the rainy season, the salinity distribution of the waters within Bahía Honda and up to $8 \mathrm{~km}$ offshore changed completely due to the large input of fresh water. At that time of year, salinities were between 25 and 30 in the first $20 \mathrm{~m}$ of the water 
(A)

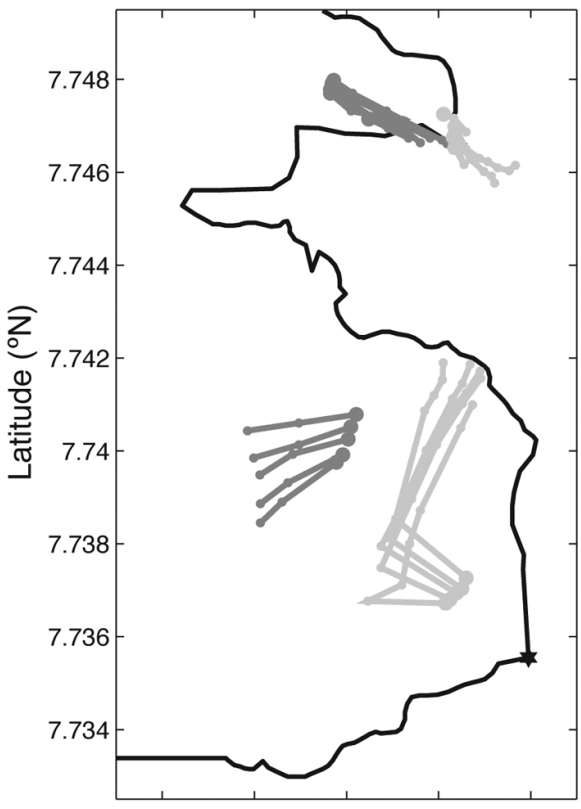

$-81.504-81.502-81.5-81.498-81.496$
(B)

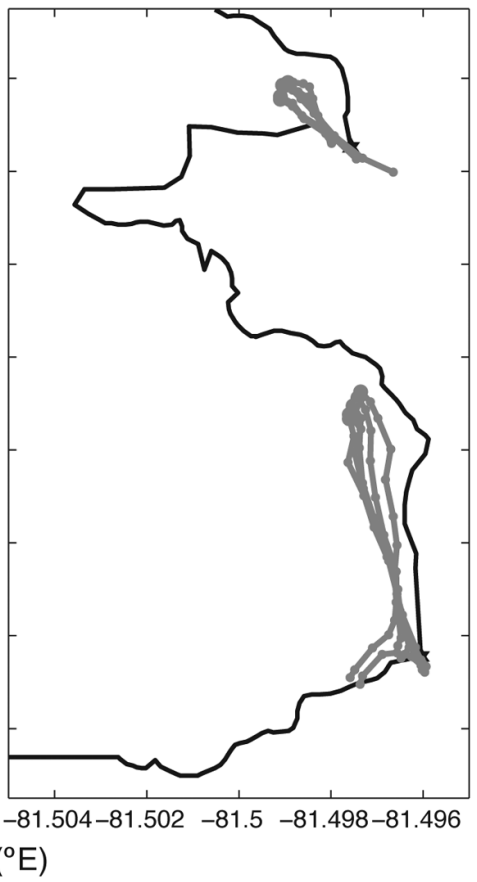

Net drifter displacements 50 min past deployment

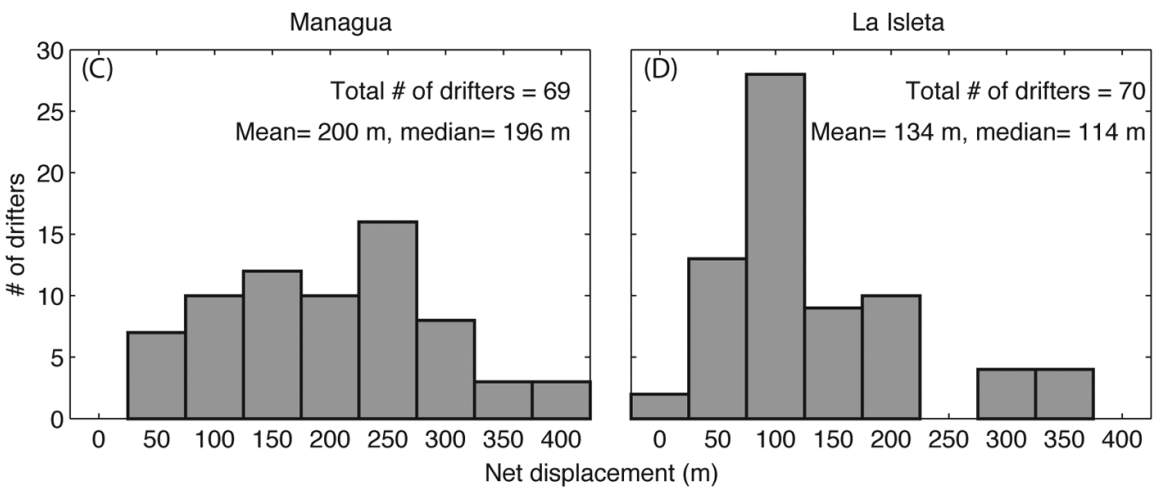

Figure 3. Top panels: selected drifter trajectories for the (A) rainy (25 November, 2005) and (B) dry (26 March, 2006) seasons. Large points represent deployment location. Drifter experiments started (A) $3 \mathrm{hrs}$ past and (B) $3 \mathrm{hrs}$ preceding peak flood. Bottom panels: histograms of net drifter displacements 50 min past deployment for all drifter experiments in (C) Managua and (D) La Isleta bays.

column, while more homogeneous and saltier conditions were found during the dry season, with salinities around 33 for the top $20 \mathrm{~m}$ (Fig. 1B,C).

Dispersion.-Net drifter displacements 50 min after deployment were variable. Nonetheless, they were generally larger for waters adjacent to Managua than for waters at La Isleta (Fig. 3C,D). Fifty min after deployment, $\sim 60 \%$ of drifters were within $200 \mathrm{~m}$ of their deployment site in Managua. In La Isleta, dispersion was less: $80 \%$ of the drifters were within $200 \mathrm{~m}$. Differences in drifter dispersion suggest greater lar- 
val dispersal (i.e., less larval retention) in waters adjacent to Managua than in those adjacent to La Isleta. However, this assumes that larvae behave as passive particles or that larvae behave in ways that would not restrict dispersal in conditions when dispersion of drifters was high.

\section{Biological Measurements}

Bioassay Larval Experiments.-For Experiments 1 and 2, the salinity of Managua water was 0.1 (Fig. 4A), and all nauplii died when added to the Managua water treatment replicate containers. Mean proportion of survivors in the other water treatments (salinities ranging from 14 to 25$)$ was high ( 0.88 or higher) and did not differ between water treatments in either Experiment 1 or 2 (Table 1). In the dry season (March 2006), we conducted Experiments 3 and 4, which had different salinities of Managua water due to date of water collection. In Experiment 3, the salinity of Managua water was 24, while the salinity in the other water treatments was 33. Mortality of cyprids did not differ between water treatments (Table 1, Fig. 4B), but nearshore cyprids had slightly higher mean mortality than offshore cyprids $(P=0.044)$. In Experiment 4, water treatment in Managua was collected at slack high tide, and the salinity was 6 . Water treatment was a significant factor: all of the nauplii died when placed in this water treatment, as did most cyprids (Table 1, Fig. 4C). No differences were observed among the remaining treatments with survivorship $>0.92$.

Larval Settlement Plates.-Settlement was very low on plates in both lagoons during both seasons. In November 2005, a single barnacle was found on one La Isleta caged plate, and two settlers were found on one plate in Managua. In March 2006, there was no settlement in Managua while in La Isleta, four uncaged plates had settlers (mean \pm SE, $1.00 \pm 0.32$ ), and only one caged plate had settlers $(0.75 \pm 0.56)$. Due to the low settlement, no statistical analysis was performed.

Larval Settlement-Mangrove Roots.-In the 5-7 d deployments, barnacles settled on $R$. mangle root segments in the dry season (March 2006), but not during the rainy season (November 2005). In the dry season, mean settlement on roots did not differ significantly during the $7 \mathrm{~d}$ deployment (ln-transformed data, Welch $\mathrm{t}$-test: $\mathrm{t}=0.128$, $\mathrm{df}=11.5, \mathrm{P}=0.901)$ between Managua (mean $\pm \mathrm{SE}, 29.38 \pm 20.46)$ and La Isleta (22.63 \pm 14.15).

Survival of Young Barnacles. - The proportion of barnacles per day that were alive after 5-6 d (November 2005) and $7 \mathrm{~d}$ (March 2006) did not differ significantly between lagoons in either season. In the rainy season, $\sim 61 \%$ of the original barnacles survived, i.e., between 0.10 and 0.13 barnacles $\mathrm{d}^{-1}$ (November 2005; Managua, mean proportion live $\mathrm{d}^{-1} \pm \mathrm{SE}, 0.104 \pm 0.014 ;$ La Isleta, $0.126 \pm 0.012, \mathrm{t}=1.208, \mathrm{df}=15.8, \mathrm{P}$ $=0.245)$. In contrast, $\sim 86 \%$ survived in the dry season or 0.12 barnacles $\mathrm{d}^{-1}$ deployed (March 2006; Managua, $0.122 \pm 0.007$; La Isleta, $0.124 \pm 0.008 ; \mathrm{df}=13.3, \mathrm{t}=0.169, \mathrm{P}$ $=0.868)$.

Recruitment.-In deployments lasting one season, variation in recruitment among stations within estuaries was high $(\mathrm{P}<0.001$, Table 3$)$, and this reduced the power to detect differences in mean recruitment between deployments. Mean number of live barnacles on plates did not differ significantly between deployments $(P=0.263)$. Over all seasons, plates in La Isleta had higher recruitment than plates in Managua (Fig. 5A,B). Significantly more barnacles were collected on caged plates than on un- 


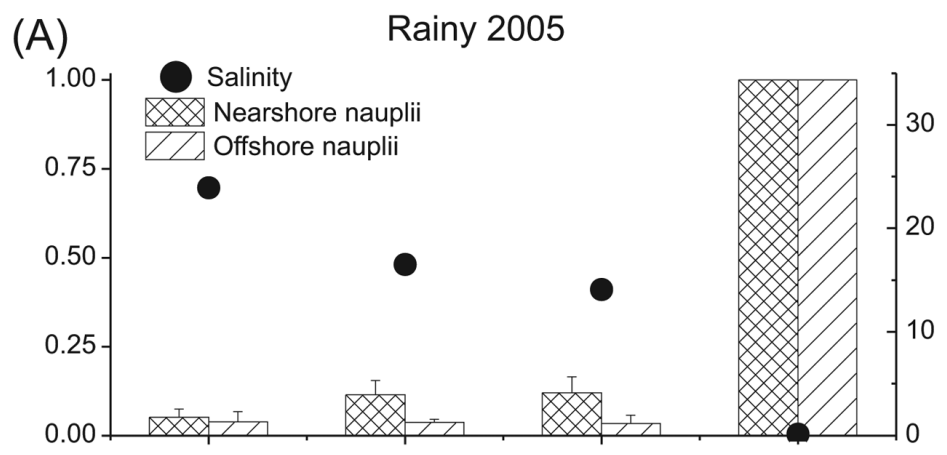

(B)

Dry 2006
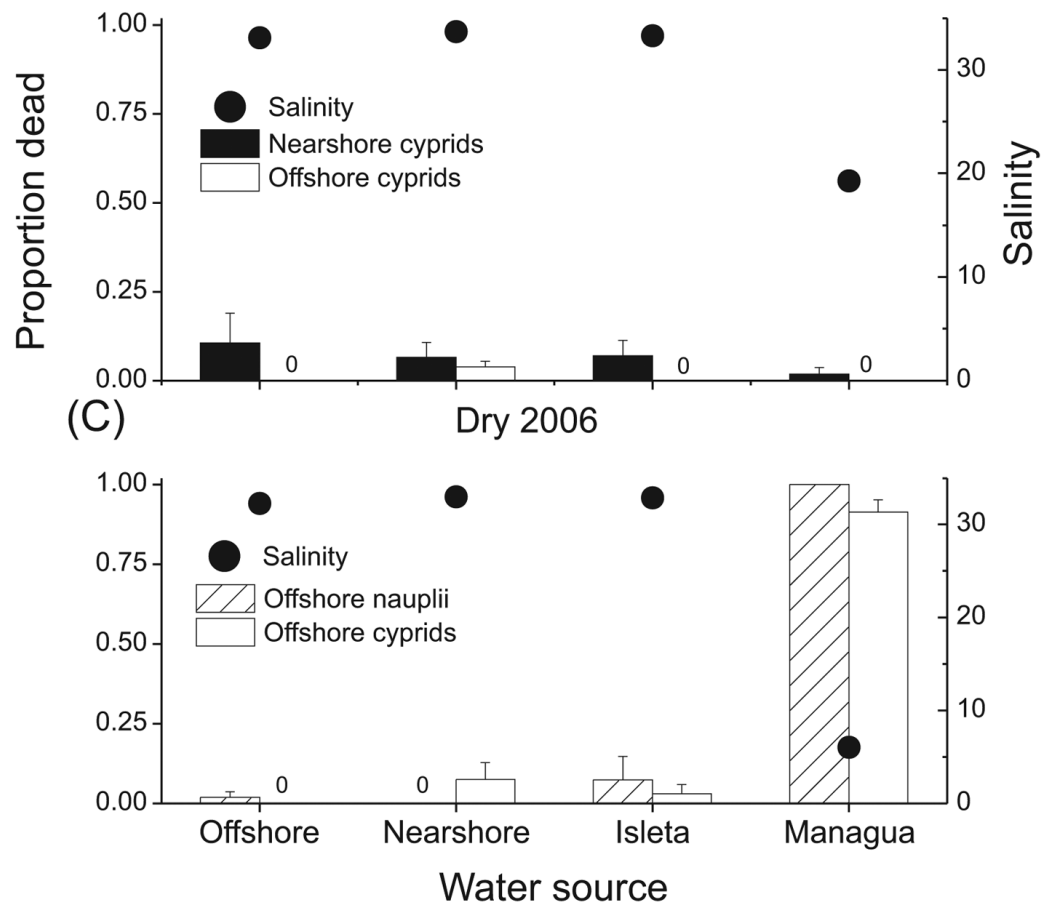

Figure 4. Mean proportion of dead larvae in bioassay experiments with (A) nauplii in the rainy season (Experiment 1), (B) cyprids in the dry season 2006 (Experiment 3), and (C) cyprids and nauplii in the dry season 2006 (Experiment 4). Note salinity of Managua water differed among experiments. Results for Experiment 2 were similar to Experiment 1 and are not shown.

caged plates (Table 3, $\mathrm{P}=0.001$ ) in most locations in La Isleta (Fig. 5C,E,G), suggesting that protection from predators or hydrodynamic effects of the cages may have enhanced recruitment.

There was a strong spatial component in recruitment within the lagoons; highest recruitment in both lagoons was at the locations closest to the mouth (Fig. 5C-H). To determine the influence of the results on the data collected at the mouth sites, the ANOVA was repeated excluding data from the mouth location in each lagoon. The results were similar [Lagoon $(\mathrm{P}=0.001)$, Cage $(\mathrm{P}<0.001)$, and Location (Lagoon $\times$ 


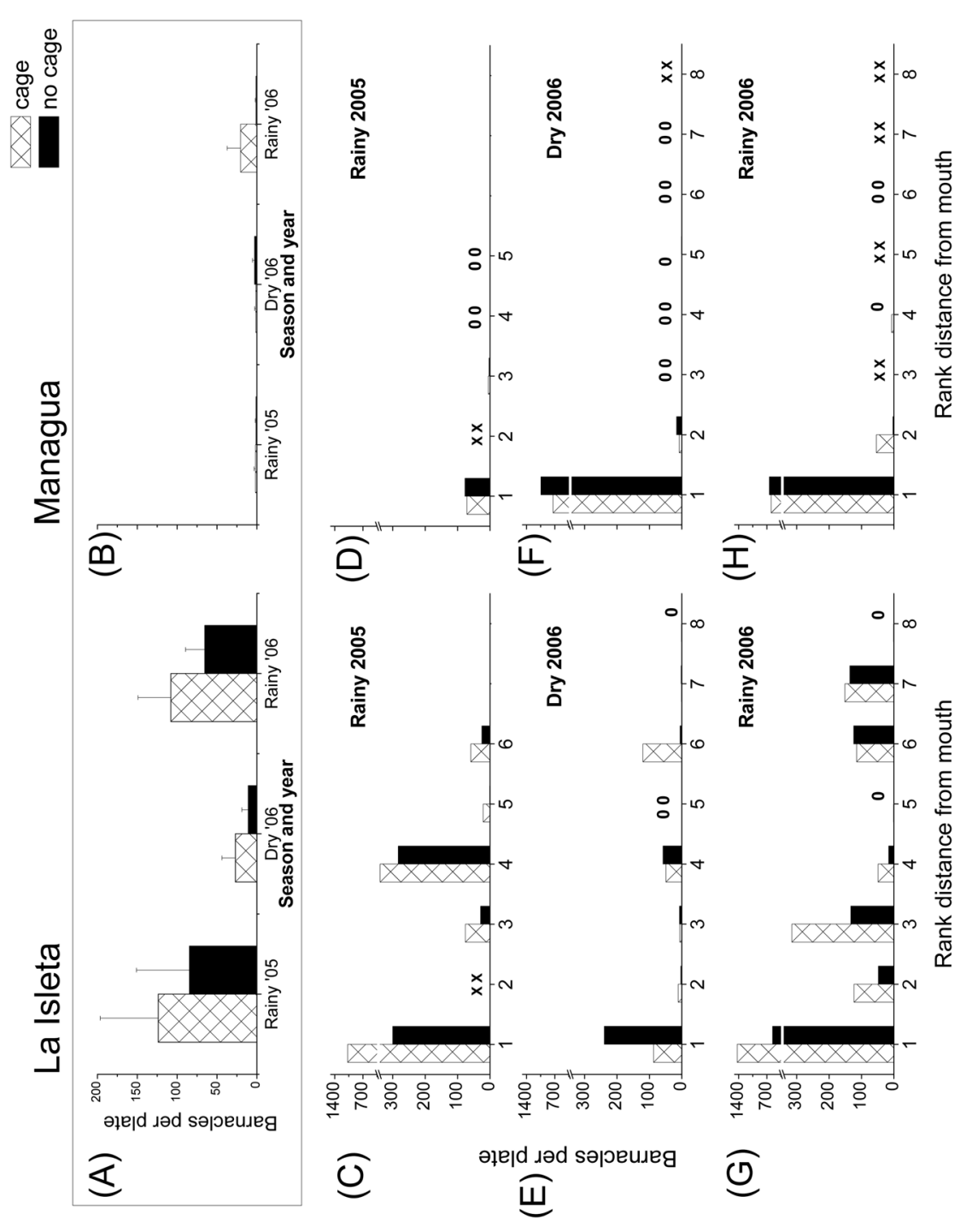

는 $\frac{0}{0}$

$3 \underset{1}{3}$

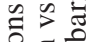

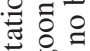

क⿺

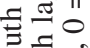

ठॄี

ठี..

密 $气$

늘

ธิํ음

$\Xi \Xi$

돈

J $x$

कo एँ

충

\&

$\Rightarrow$

可

䒕

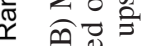

氖焉

ㄴ.

픈 즐

प्र

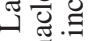

<

$\Xi$ 픈

过它

를

可吉

용

函

늘

元

क्ष

ธี 를

을

造

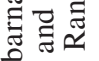

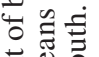

氙 ฏ

范号

들

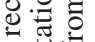

(1)

के 믈

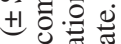

政

인는

เं 0

0

을 므

顽司 
Table 3. ANOVA results for recruitment of barnacles on caged and uncaged plates in two lagoons during three long-term deployments. Data from the plates at the lagoon mouth were included in analysis. Bold indicates statistical significance.

\begin{tabular}{lcrrc}
\hline Source & Sum-of-squares & df & F-ratio & P-value \\
\hline Deployment & 27.609 & 2 & 1.397 & 0.263 \\
Lagoon & 43.633 & 1 & 4.416 & $\mathbf{0 . 0 4 4}$ \\
Cage & 4.585 & 1 & 12.980 & $\mathbf{0 . 0 0 1}$ \\
Lagoon $\times$ deployment & 11.767 & 2 & 0.595 & 0.558 \\
Cage $\times$ deployment & 2.262 & 2 & 3.201 & 0.055 \\
Cage $\times$ lagoon & 0.622 & 1 & 1.760 & 0.195 \\
Cage $\times$ lagoon $\times$ deployment & 1.646 & 2 & 2.330 & 0.115 \\
Location (lagoon $\times$ deployment) & 296.433 & 30 & 27.971 & $<\mathbf{0 . 0 0 1}$ \\
Error & 10.598 & 30 & - & - \\
\hline
\end{tabular}

Deployment, $\mathrm{P}<0.001)$ ], but the Deployment $\times$ Lagoon $\times$ Cage term became significant $(\mathrm{P}=0.047)$. When pairwise comparisons of the means were made with data that excludes the plates at the mouth of each lagoon, recruitment was higher in La Isleta during the wet season than during the dry season (Table 4), although we expected recruitment to be lower during the wet season when salinity levels are lower. Overall, recruitment on plates was low inside of Managua in all deployments. The highest recruitment in Managua was during the second wet season, which was not expected given the very low salinity levels measured within Managua at that time (Fig. 2D). Low numbers of recruits in Managua made differences between caged and uncaged plates difficult to detect.

If settlement differs with substrate, a preference to settle on Rhizophora roots may help explain the higher number of recruits observed at La Isleta compared to Managua: Rhizophora and Pelliciera are the dominant trees in La Isleta, while Avicennia is more prevalent in Managua. However, we found that mean recruitment on Pelliciera was slightly higher than on Rhizophora roots $(\mathrm{P}=0.025$, Tukey-Kramer test), but no other differences in recruitment between root types were significant (Fig. 6A,B, Table 5). Recruitment was not significantly different between lagoons or deployments. Mean recruitment varied with distance from the mouth of the lagoons. In both seasons, recruitment was highest at the mouth of each lagoon (Fig. 6C-F). Excluding recruitment data on the substrates at the mouth of each estuary made no difference to the results.

Table 4. Results of pairwise comparison of means computed after excluding plates at the lagoon mouth. Lines connect means that were not significantly different within a deployment. Similar letters designate means that were not different between seasons within a lagoon and plate treatment.

\begin{tabular}{|c|c|c|c|c|}
\hline & \multicolumn{2}{|c|}{ La Isleta } & \multicolumn{2}{|c|}{ Managua } \\
\hline & Cage & Uncaged & Caged & Uncaged \\
\hline \multirow[t]{2}{*}{ Wet 2005} & $\mathrm{~A}$ & $\mathrm{~A}$ & $\mathrm{AB}$ & $\mathrm{A}$ \\
\hline & 123.50 & 84.5 & 1.67 & 1.00 \\
\hline \multirow[t]{2}{*}{ Dry 2006} & B & B & A & A \\
\hline & 26.85 & 10.7 & 1.33 & 2.83 \\
\hline \multirow[t]{2}{*}{ Wet 2006} & A & $\mathrm{A}$ & B & A \\
\hline & 107.90 & 65.3 & 20.30 & 1.00 \\
\hline
\end{tabular}




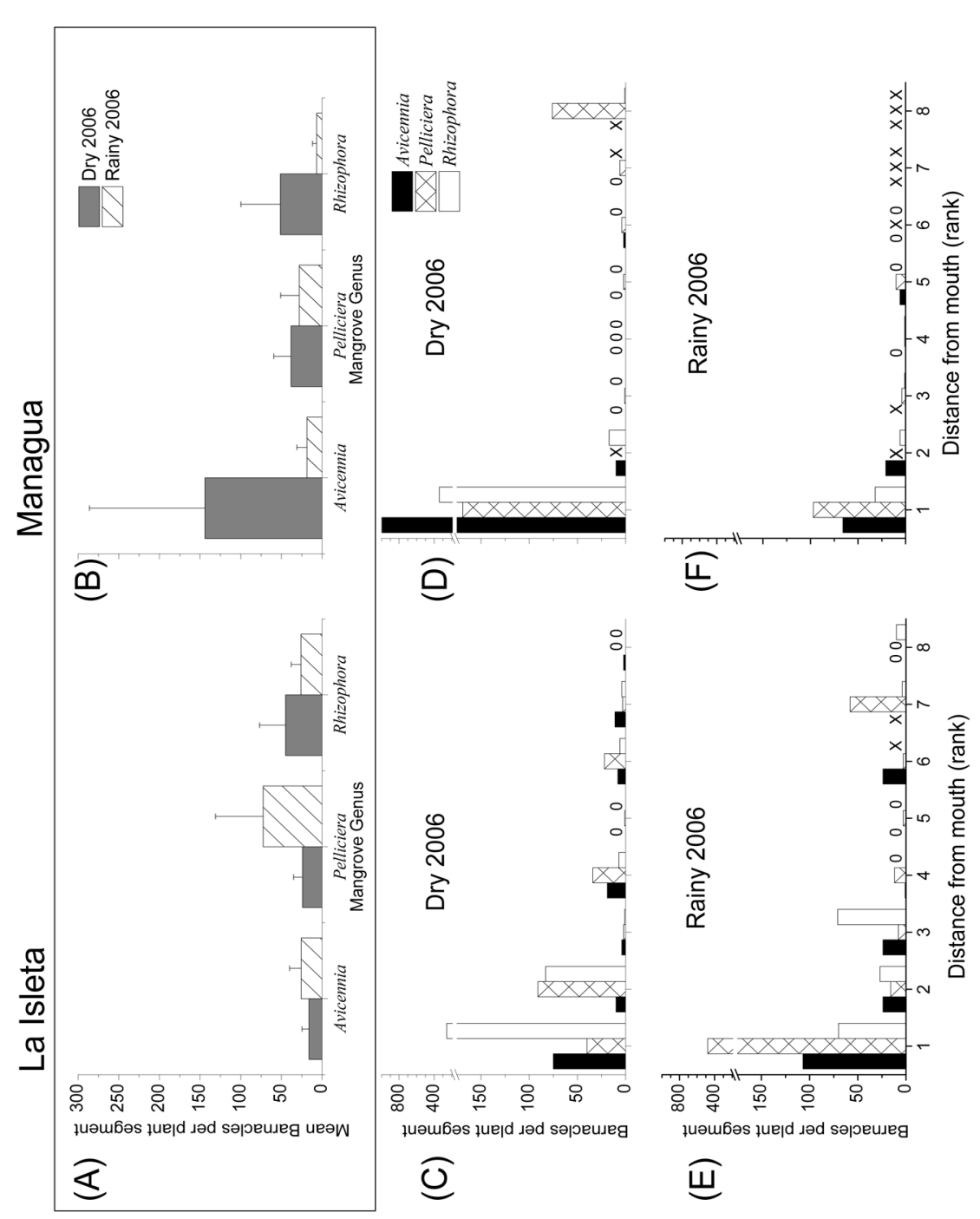

of $\frac{v}{2} \frac{0}{v}$

छ

要跤

$\stackrel{0}{\circ}$

¿

ธo․ㅡㅇ

8 .

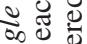

క. $\Xi$

胥

$\div$.

원

으음

ป. $\Xi$

胥

즐

政

¿

20

을

늘

๘ี

डิ

证

2.

를

$\Xi \Xi$

.

플

s. oै

$\infty \div$

플

ฮิ สี

डे

ธิธ

के ह ह

흐

荭

0 1

능

䜦

छี

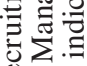

อิ-

Iิ븐

ऽ ซี

†

표

这

6 워

들

$\exists$ \&

6. 
Table 5. ANOVA results of mean recruitment of barnacles on three roots in each lagoon during the rainy and dry season deployments. Number of live barnacles on each root was $\ln (x+1)$-transformed. Bold indicates statistical significance.

\begin{tabular}{lcccc}
\hline Source & Sum-of-squares & df & F-ratio & P-value \\
\hline Deployment & 0.175 & 1 & 0.214 & 0.885 \\
Lagoon & 5.574 & 1 & 6.781 & 0.418 \\
Lagoon $\times$ deployment & 0.208 & 1 & 0.253 & 0.875 \\
Root & 6.143 & 2 & 3.737 & $\mathbf{0 . 0 3 2}$ \\
Root $\times$ deployment & 0.004 & 2 & 0.003 & 0.997 \\
Root $\times$ lagoon & 2.264 & 2 & 1.377 & 0.263 \\
Root $\times$ lagoon $\times$ deployment & 0.203 & 2 & 0.123 & 0.884 \\
Location (lagoon $\times$ deployment) & 213.919 & 26 & 10.010 & $<\mathbf{0 . 0 0 1}$ \\
Error & 36.989 & 45 & - & - \\
\hline
\end{tabular}

Population Persistence.-Persistence appears higher in La Isleta than in Managua, although variability among locations was large (Fig. 7, Table 2). The rainy season 2006 deployment resulted in no live barnacles in Managua, and the mean number of live barnacles recovered from La Isleta was significantly $>0$ for this deployment (one sample t-test, Table 2). However, the mean number of live barnacles on $R$. mangle roots was not significantly different between the two coastal lagoons in the rainy 2005 or the dry 2006 season (Table 2). It is not known how many of the original barnacles deployed in the lagoons during any season survived on each root, but small, newly settled barnacles were among the live barnacles found in both lagoons. Hence, barnacles recruited onto roots, suggesting that populations persisted in both lagoons seasonally.

\section{DISCUSSION}

Hydrographic measurements and laboratory and field experiments suggest that the low abundance of epibionts in Managua mangroves is due to the effects of presettlement processes, including (1) low salinity waters increasing larval mortality, and perhaps influencing juvenile survival, and (2) high flushing rates and dispersion

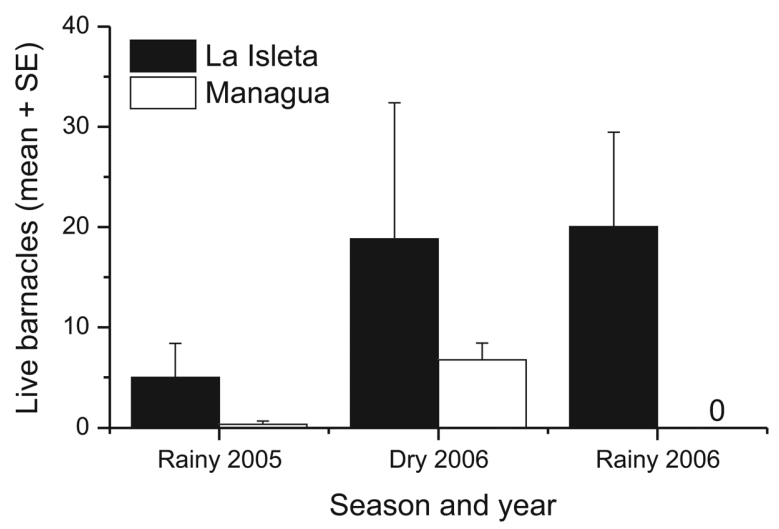

Figure 7. Population persistence (survival plus recruitment) and number of live barnacles collected on root segments affixed with either 25 (Rainy 2005) or 20 small barnacles (Dry and Rainy 2006). 
that may reduce larval supply during the rainy season in Managua. Post-settlement processes in the form of paucity of barnacle populations in Managua may potentially further reduce larval supply and settlement. Assuming self-recruitment in Managua, low adult numbers would result in fewer larvae being produced, further reducing adult abundance. We expect most larvae invading Managua in every tidal cycle would originate in the adjacent Bahía Honda. However, we cannot rule out self-recruitment within Managua during the dry season based on residence time and larval duration of the resident barnacles (White et al. 2010). Thus, a combination of seasonal differences in salinity, flushing, and abundance of resident barnacles appears to determine barnacle abundance in Managua.

\section{HYDRODYNAMICS}

In estuaries fringed by mangroves, water flow experiences greater drag and turbulence from inundated roots and trees, which can lead to higher retention of passive particles than in other estuarine systems. The drag force increases with vegetation length scale, which is a function of the area of mangrove vegetation and volume of vegetation (Mazda et al. 1997). We did not measure vegetation length scale in either of the two systems, but it appeared that mangrove vegetation was denser at La Isleta, with a predominance of Rhizophora, than in Managua, with mixed stands of Pelliciera, Avicennia, and Rhizophora. Therefore, a trapping effect (and hence larval retention) may be stronger in La Isleta than in Managua when runoff is low. This would occur only if the mangrove area is the same or larger in La Isleta than in Managua.

In the presence of freshwater runoff, a cross-channel secondary circulation may result from the deformation of the along-channel salinity gradient, caused by crosschannel shear in the tidal channel flow and the off-phase release of trapped fresh water during ebb flow. This process results in a convergence at the center of the channel during flood, and buoyant material accumulates along the front. During ebb, a divergence pushes material toward the channel boundary. If river input is not large enough to flush all surface water out of the lagoon, a net landward movement of floating material, such as mangrove seeds, occurs (Ridd et al. 1998).

Barnacle larvae may take advantage of the hydrodynamics of their environment by swimming vertically to be driven onshore by internal tidal bore fronts (Pineda 1999), and by selectively entering the water column during night-time high tides, as in a mangrove forest in Sydney, Australia (Ross 2001). Thus, cyprids may actively use convergences and divergences due to secondary circulations within Managua to reach roots to settle. This may help maintain the small population within Managua during the dry and early wet season. Nevertheless, the lagoon's channels are narrow and shallow, so it is likely that turbulent channel flow erodes away cross-channel salinity gradients, preventing the development of density driven secondary circulation.

\section{SALINITY}

Managua waters were fresher than offshore, nearshore, and La Isleta waters during the dry and the rainy seasons, but only in the rainy season were salinities low enough to kill all the nauplii tested as well as the majority of cyprids. Managua waters killed larvae when salinities were $<6$, which are common salinities in the rainy season (Fig. 2D). The effects of salinity on adult and larval barnacle survival and on larval settlement abilities vary with species (Crisp and Costlow 1963, Bhatnagar and Crisp 1965, Sandison 1966, Foster 1970, Dineen and Hines 1992, Chan et al. 2001, Marques-Silva 
et al. 2006), but the lowest salinity in which nauplii and cyprids from Bahía Honda can survive is unknown. Although nauplii and cyprids survived in salinities between 6 and 15, this does not assure recruitment. In laboratory experiments with Balanus trigonus (Darwin, 1854), Thiyagarajan et al. (2003) found that larvae develop rapidly in warm waters, but they are less likely to attach when salinity is low, which may explain low recruitment in Hong Kong during the summer months.

Availability of larvae in the lagoons may vary seasonally. During the dry season, water from Bahía Honda enters Managua during flood tide, so some larval transport into Managua is expected. We collected cyprids and nauplii in plankton tows taken $200 \mathrm{~m}$ inside Managua during flood tide in March 2006 (V Starczak and H Levine, unpubl data), whereas tows taken during the rainy season had no larvae. In Lagos Harbor, Nigeria, nauplii of Balanus pallidus stutsburi (Darwin, 1853) were in the harbor during the dry season, but not during the rainy season, when salinities were as low as 0.6 (Sandison 1966). In contrast, peak settlement of the barnacle Fistulobalanus citerosum (Henry, 1973) occurred during the wet season in the Caeté mangrove estuary in northern Brazil (Marques-Silva et al. 2006).

The effects of low salinity on settled juveniles and adult barnacles in Bahía Honda are unclear. Low-salinity water may cause blood dilution, and the degree of blood dilution that barnacles can tolerate is species-specific. Some species can survive immersion in low salinity water by closing their opercular plates (Foster 1970). Our short-term young-barnacle survival experiments show no survivorship differences in La Isleta and Managua during the dry and rainy seasons, yet survival was higher during the dry season in both coastal lagoons. Barnacles may be able to withstand low salinity events for 5-7 d, although the effects of immersion in low salinity water may only be detected after several weeks if barnacles have closed opercular valves (i.e., not feeding).

\section{FLUSHING}

Mean dispersion distances of surface drifters in the water bodies adjacent to Managua were generally larger than in waters adjacent to La Isleta. In the rainy season, surface drifters during peak flood tide consistently headed toward La Isleta, but drifted away from Managua's mouth. In these conditions, surface material originating in the bay would not have a chance to enter Managua. Surface dwelling larvae may drift away from Managua, reducing overall larval supply (i.e., number of larvae near settlement sites).

\section{Recruitment and Persistence}

Recruitment on plates and on mangrove segments was lower in Managua than in La Isleta, though there was large variability within lagoons. This is consistent with our findings that Managua is generally a more adverse environment for barnacle populations than La Isleta: more larvae were killed by fresh water, flushing was greater, and there were smaller resident populations supplying larvae (see below). Caged plate treatments had generally more recruitment than non-caged ones, a result that might be explained by predation. In a mangrove estuary in the west coast of Costa Rica, hermit crabs forage on newly settled barnacles on Rhizophora prop roots that are in contact with the substrate (Perry 1988). In our deployments, plates and roots were always fastened to mangrove roots that were attached to the substrate, and mesh size was sufficiently small to exclude most crabs, snails, and fishes. However, 
we do not know whether predation pressure varied between Managua and La Isleta, or whether there were small predators (e.g., nemertean worms).

Population persistence in benthic sessile species depends on survival of existing individuals and recruitment of new ones. Our results suggest that barnacle persistence was higher in La Isleta than in Managua in one wet season (albeit there is no evidence of statistical differences in two other seasons), suggesting that long-term exposure to low salinity and flushing in Managua may result in decreased population persistence. Root integrity could have changed during the deployment, but mangrove segments with barnacles that were transplanted generally showed little decay. It is not known whether dead segments have fewer recruits than live segments. However, the experiments can be applied to recruitment on dead mangrove roots, which are often found in these environments. At the end of the experiments, the number of live barnacles in La Isleta was generally lower than the initial number of transplanted individuals, implying declining initial colony size with time.

Barnacle populations on mangroves at the mouth of La Isleta and Managua are larger and denser than at other sites inside the lagoons, and this spatial pattern is consistent with higher recruitment on plates and roots near the mouth of the lagoon than at sites away from the mouth. More water flows through the mouth of each lagoon than through any other site inside the lagoon; substrates at these sites would be exposed to more larvae than at other sites (assuming a uniform distribution for the larvae). Most recruitment of Eliminius covertus (Foster, 1982) in a mangrove forest in southeastern Australia was at the seaward edges of the forest (Ross and Underwood 1997, Satumanatpan et al. 1999), where supply of cyprids was the highest (Ross 2001, Satumanatpan and Keough 2001). Higher recruitment and abundance at sites near the mouth of each coastal lagoon may be a consequence of the high water flux and, for Managua, more saline conditions near the mouth.

The high densities of adult barnacles at the entrance of the lagoon and at the bay suggest that the source of larvae settling inside of La Isleta and Managua originate outside the lagoons. However, we cannot reject the idea that some larvae settling in the lagoons originate from lagoon adult populations. We speculate that the paucity of local populations inside Managua may further reduce larval supply and settlement relative to La Isleta. This would be likely if barnacle settlers were gregarious, settling predominantly near other settled individuals (e.g., a positive feedback mechanism). Moreover, if larvae complete their entire development, from release to competence, inside the lagoon (implying retention), larger barnacle populations would be expected in La Isleta than in Managua, since Isleta adults would produce Isleta larvae that could then settle in La Isleta. This is speculative as the proportion of self- vs non-self recruitment is unknown. Self-recruitment may be possible as some warm water barnacle species can complete larva development within a few days, i.e., 5-12 d (Karande 1974), and many barnacle species are gregarious (Knight-Jones 1953).

\section{Out-of-Phase Stresses}

It is not surprising that a coastal lagoon with high freshwater input, more flushing, and smaller resident barnacle populations had less recruitment than a nearby system with opposite characteristics. What is surprising, however, is the overall paucity of epibionts and sessile benthic organisms in this region compared to mangrove systems in the Caribbean or in Pacific Mexican mangroves (J Pineda, pers obs). Other factors that could contribute to the paucity of sessile organisms on mangrove roots 
and nearby habitats include (1) secondary metabolites that prevent herbivory on the tropical rainforest flora that may accumulate in nearshore waters and cause larval mortality [e.g., Alongi (1987) for meiofauna in sediments near mangrove]. This hypothesis was discarded as an explanation for the greater abundance of sessile populations in La Isleta than in Managua because it predicts longer residence times in Managua than in La Isleta (conducive to more leaching of tropical forest secondary metabolites), a prediction contradicted by Managua having larger flushing rates during the rainy season. Another factor is (2) low $\mathrm{pH}$, a result of oxidized organic matter that may be lethal to species with a calcium carbonate shell, such as barnacles, mussels, and oysters (Middelburg et al. 1996). A survey measuring $\mathrm{pH}$ content in sediments (results not shown) showed no significant differences between La Isleta and Managua sediments, and hence this hypothesis was discarded as an explanation for differences between the two lagoons.

In addition to the paucity of sessile fauna on mangrove roots, species richness of some benthic taxa (including corals) is also low (Glynn 2001) along the Pacific coast of Panama. Large seasonal input of fresh water to the system may have a strong negative effect on intertidal and shallow subtidal marine populations during the rainy season from May to early December, and factors that impinge on the epibiont barnacles in Managua may affect other invertebrate species. From January through April, roughly the dry season, the thermocline becomes shallow in the region of our study (Dana 1975, Jimenez 2001, Pineda et al. 2009), and the thermocline shallows up to 2-3 m water depth in an open-coast site nearby Bahía Honda (Pineda et al. 2009). It is likely these cool waters enter Bahía Honda, but it is not known whether they affect intertidal mangrove barnacles. When the thermocline is deep, the internal tide may only affect deep benthic communities. The shallowing of the thermocline allows surges of cold water associated with the internal tide to intrude into shallower water [e.g., Pineda and Lopéz (2002) for Southern California], and this may stress subtidal populations (Coles and Fadlallah 1991). Moreover, observations at a nearby observatory (Gallager et al., unpub data) indicate that low oxygen is sometimes correlated with these cold surges. Thus, while in the rainy season, low salinities associated with very heavy precipitation may stress intertidal species and shallow subtidal species; in the dry season, hard-substrate, shallow-subtidal fauna may be impacted by cold water surges associated with the internal tide in the area (Dana 1975, Pineda et al. 2009).

In summary, our study of pre- and post-settlement factors influencing epibionts in the mangrove systems of the Pacific coast of Panama, a region characterized by very high precipitation during 7 mo of the year, and the shallowing of cool water for the rest of the year (Pineda et al. 2009), suggests that intertidal and shallow subtidal populations are naturally stressed. Adverse conditions at different times of the year appear to result in sparse benthic populations, but more studies are required to evaluate the role of other factors in maintaining these low populations.

\section{ACKNOWLEDGMENTS}

VS, PP-B, and JP contributed equally to this study. Much of the fieldwork was successful thanks to LA CACHORrA and El LoBo captains, L Gutiérrez (Pacho) and B Castillo, and park ranger, B Santos. Their knowledge of the area and the natural history of the coastal species, as well as their great disposition were crucial for completing this study. We thank the staff at the Liquid Jungle Laboratory (L Kline, X Oliver, H Whitney, D Colombo, G Colombo, and M Zannini), for support with logistics, housing, and material. I Madrid also contributed some time 
as helmsman. E González fed us well during those intensive field days. T Elsdon offered much appreciated help on our last visit. F Pitombo (Universidade Federal Fluminense, Niterói, Rio de Janeiro, Brazil) kindly identified the barnacles. L Camilli provided his watershed analysis map. X López-Medellín offered fruitful discussions. We appreciate the reviewers' comments. Finally, we would like to thank the Ocean Life Institute of the Woods Hole Oceanographic Institution for funding to JP to complete research in the Liquid Jungle Lab.

\section{Literature Cited}

Alongi DM. 1987. The influence of mangrove-derived tannins on intertidal meiobenthos in tropical estuaries. Oecologia. 44:537-540. http://dx.dol.org/10.100//BF00379293

Bhatnagar KM, Crisp DJ. 1965. The salinity tolerance of nauplius larvae of cirripedès. J Anim Ecol. 34:419-428. http://dx.doi.org/10.2307/2658

Bingham BL. 1992. Life histories in an epifaunal community: coupling of adult and larval processes. Ecology. 73:2244-2259. http://dx.dol.org/10.2307/19414/2

Blythe , Pineda J. 2009. Habitat selection at settlement endures in recruitment time series. Mar Ecol Prog Ser. 396:77-84. http://dx.doi.org/10.3354/meps08309

Brownlee KA. 1965. Statistical theory and methodology in science and engineering. 2nd ed. New York: Wiley Publishing.

Camilli L. 2007. Advancing spatial-temporal continuity in coral reef ecosystem pattern detection. MS. Thesis. Moss Landing Marine Laboratories. San Jose, California, San Jose State University: 189.

Chan BKK, Morritt D, Williams GA. 2001. The effect of salinity and recruitment on the distribution of Tetraclita squamosa and Tetraclita japonica (Cirripedia; Balanomorpha) in Hong Kong. Mar Biol. 138:999-1009. http://dx.doi.org/10.1007/s002270000531

Chong VC, Sasekumar A, Wolanski E. 1996. The role of mangroves in retaining penaeid prawn larvae in Klang Strait, Malaysia. Mangroves Salt Marshes. 1:11-22. http://dx.doi. org/10.1023/A:1025938010474

Coles SL, Fadlallah YH. 1991. Reef coral survival and mortality at low temperatures in the Arabian Gulf; new species-specific lower temperature limits. Coral keefs. 9:231-237. http:/1 dx.dol.org/10.1007/BFO0290427

Connell JH. 1985. The consequences of variation in initial settlement vs post-settlement mortality in rocky intertidal communities. J Exp Mar Biol Ecol. 93:11-45. http:/ddx.doi. org/10.1016/0022-0981(85)90146-7

Crisp DJ, Costlow Jr JD. 1963. The tolerance of developing cirripede embryos to salinity and temperature. Oikos. 14:22-34. http://dx.doi.org/10.2307/3564957

Dana IF. 1975. Development of contemporary eastern Pacific coral reefs. Mar Biol. 33:355374. http://dx.doi.org/10.1007/BF00390574

Dineen Jr JF, Hines AH. 1992. Interactive effects of salinity and adult extract upon settlement of the estuarine barnacle Balanus improvisus (Darwin, 1854). J Exp Mar Biol Ecol. 156:239252. http://dx.dol.org/10.1016/0022-0981(92)90249-A

Duke NC, Bali MIC, Ellison JC. 1998. Factors influencing biodiversity and distributional gradients in mangroves. Global Ecol Biogeogr Lett. 7:27-47. http://dx.doi.org/10.2307/2997695

Ellison AM. 2004. Wetlands of Central America. Wet Ecol Manag. 12:3-55. http://dx.doi. org/10.1023/B:WETL.0000016809.95746.b1

Farnsworth EJ, Ellison AM. 1996. Scale-dependent spatial and temporal variability in biogeography of mangrove root epibiont communities. Ecol Monogr. 66:45-66. http://dx.doi. org/10.2307/2963480

Foster BA. 1970. Responses and acclimation to salinity in the adults of some balanomorph barnacles. Philos Trans K Soc London, Ser B. 256:377-400.

Gimenez L. 2004. Marıne community ecology: 1mportance of trait-mediated effects propagating through complex life cycles. Mar Ecol Prog Ser. 283:303-310. http://dx.doi.org/10.3354/ meps 283303 
Glynn PW. 2001. Eastern Pacific coral reef ecosystems. In: Seeliger U, Kjerfve BJ, editors. Coastal Marine Ecosystems of Latin America. Berlin: Springer Publishing. p. 281-305.

Hatton H. 1938. Essais de bionomie explicative sur quelques espèces intercotidales d'algues et d'animaux. Annls Inst Océanogr Monaco. 17:241-348.

Jarrett JN. 2003. Seasonal variation in larval condition and postsettlement performance of the barnacle Semibalanus balanoides. Ecology. 84:384-390. http://dx.doi.org/10.1890/00129658(2003)084[0384:SVILCA]2.0.CO;2

Jimenez C. 2001. Seawater temperature measure at the surface and at two depths (7 and 12 m) in one coral reef at Culebra Bay, Gulf of Papagayo, Costa Rica. Rev Biol Trop. 49(Suppl 2):153-161. PMid:15264529.

Karande AA. 1974. Larval development of the barnacle Tetraclitella karandei reared in laboratory. Biol Bull. 146:249-257. PMid:4822763. http://dx.doi.org/10.2307/1540621

Karuppaiyan M, Raja K. 2007. Effect of tides on settlement of oysters and barnacles in Pichavaram mangrove of the southeast coast of India. Res J Environ Sci. 1:324-330. http:// dx.doi.org/10.3923/rjes.2007.324.330

Kalnay E, Kanamitsu M, Kistler R, Collins W, Deaven D, Gandin L, Iredell M, Saha S, White G, Woollen J, et al. 1996. The NCEP/NCAR 40-year reanalysis project. Bull Amer Meteor Soc. (composites ontıne); 77:437-471. Avallable from: http://WwW.cdc.noaa.gov/cgl-bin/data/ composites/printpage.pl via the Internet. Accessed 10 Feb 2010.

Kobashi D, Mazda Y. 2005. Tidal flow in riverine-type mangroves. Wet Ecol Manag. 13:615619. http://dx.doi.org/10.1007/s11273-004-3481-4

Knight- ones EW. 1953. Laboratory experiments on gregariousness during settling in Balanus balanoides and other barnacles. J Exp Biol. 30:584-598.

Marques-Silva NS, Beasley CR, Paiva Gomes C, Lima Gardunho DC, Taliaro CH, Schories D, Mehlig U. 2006. Settlement dynamics of the encrusting epibenthic macrofauna in two creeks of the Caeté mangrove estuary (north Brazil). Wet Ecol Manag. 14:67-78. http:// dx.doi.org/10.1007/s11273-005-2568-x

Mazda Y, Kanazawa N, Wolanski E. 1995. Tidal asymmetry in mangrove creeks. Hydrobiologia. 295:51-58. http://dx.doi.org/10.1007/BF00029110

Mazda Y, Wolanski E, King B, Sase A, Ohtsuka D, Magi M. 1997. Drag force due to vegetation in mangrove swamps. Mangroves Salt Marshes. 1:193-199. http://dx.doi. org/10.1023/A:1009949411068

Mazda Y, Wolanski E, Ridd PV. 2007. Part I: outline of the physical processes within mangrove systems. In: Mazda Y, Wolanski E, Ridd PV, editors. The role of physical processes in mangrove environments: manual for the preservation and utilization of mangrove ecosystems. Japan: Terrapub. p. 3-64.

Middelburg JJ, Nieuwenhuize J, Slim FJ, Ohowa B. 1996. Sediment biogeochemistry in an East African mangrove forest (Gazi Bay, Kenya). Blogeochemistry. 34:133-155. http://dx.do1. org/10.1007/BF00000899

Morgan SG. 1995. Life and death in the plankton: larval mortality and adaptation. In: McEdward L, editor. Ecology of marine invertebrate larvae. Boca Raton: CRC Press. p. 279-321.

Ong JE, Gong WK, Wong CH, Din ZH, Kjerfve B. 1991. Characterization of a Malaysian mangrove estuary. Estuaries. 14:38-48. http://dx.doi.org/10.2307/1351980

Pérez-Brunius P, Starczak V, Pineda J, Gyory J, Levine H. 2006. Physical data report of measurements taken in Bahía Honda, Panama, during three field trips: March 2005, November 2005, and March 2006 (Population limitation at the land-sea interface: do jungle derived secondary metabolites structure marine sessile communities?). Technical Report 46744. Depto. Oceanografía Física. Mexico: CICESE.

Perry DM. 1988. Effects of associated fauna on growth and productivity in the red mangrove. Ecology. 69:1064-1075. http://dx.doi.org/10.2307/1941262

Phleger FB. 1969. Some general features of coastal lagoons. In: Ayala-Castañares A, Phleger FB, editors. Mem Simp Intern Laginas Costeras. UNAM-UNESCO. Univ Nac Auton Mex, Mexico City. p. 5-26. 
Pineda J. 1994. Spatial and temporal patterns in barnacle settlement rate along a Southern California rocky shore. Mar Ecol Prog Ser. 107:125-138. http://dx.doi.org/10.3354/ meps 107125

Pineda J. 1999. Circulation and larval distribution in internal tidal bore warm fronts. Limnol Oceanogr. 44:1400-1414. http://dx.doi.org/10.4319/lo.1999.44.6.1400

Pineda . 2000. Linking larval settlement to larval transport: assumptions, potentials, and pitfalls. Oceanogr E Pacif. 1:84-105.

Pineda J, López M. 2002. Temperature stratification and barnacle larval settlement in two Californian sites. Cont Shelf Res. 22:1183-1198. http://dx.doi.org/10.1016/S02784343(01)00098-X

Pineda J, Reyns NB, Starczak VR. 2009. Complexity and simplification in understanding recruitment in benthic populations. PopulEcol.51:17-32. http:/dx.doi.org/10.1007/s10144008-0118-0

Pineda J, Porri F, Starczak VR, Blythe J. 2010. Causes of decoupling between larval supply and settlement and consequences for understanding recruitment and population connectivity. J Exp Mar Biol Ecol. 392:9-21. http://dx.doi.org/10.1016/j.jembe.2010.04.008

Ridd PV, Stieglitz T, Larcombe P. 1998. Density-driven secondary circulation in a tropical mangrove estuary. Estuar Coast Shelf Sc1. 47:621-632. http://dx.dol.org/10.1006/ecss.1998.0383

Ros PM. 2001. Larval supply, settlement and survival of barnacles in a temperate mangrove forest. Mar Ecol Prog Ser. 215:237-249. http://dx.doi.org/10.3354/meps215237

Ross PM, Underwood AJ. 1997. The distribution and abundance of barnacles in a mangrove forest. Aust J Ecol. 22:37-47. http://dx.doi.org/10.1111/j.1442-9993.1997.tb00639.x

Sandison EE. 1966. The effect of salinity fluctuations on the life cycle of Balanus pallidus stutsburi Darwin in Lagos Harbour, Nigeria. I Anim Ecol. 35:363-378. http://dx.dol. org/10.2307/2401

Satumanatpan S, Keough MJ, Watson GF. 1999. Role of settlement in determining the distribution and abundance of barnacles in a temperate mangrove forest. J Exp Mar Biol Ecol. 241:45-66. http://dx.dol.org/10.1016/50022-0981(99)00066-0

Satumanatpan S, Keough M). 2001. Roles of larval supply and behavior in determining settlement of barnacles in a temperate mangrove torest. J Exp Mar Biol Ecol. 260:133-153. http://dx.doi.org/10.1016/S0022-0981(01)00251-9

Spađđing MD, Fox HE, Allen GR, Davidson N, Ferdaña ZA, Finlayson M, Halpern BS, Jorge MA, Lombana A, Lourie SA, et al. 2007. Marine ecoregions of the world: a bioregionalization of coastal and shelf areas. Bioscience. 57:573-583. http://dx.doi.org/10.1641/B570707

Sponaugle S, Grourud-Colvert K, Pinkard D. 2006. Temperature-mediated variation in early life history traits and recruitment success of the coral reef fish Thalassoma bifasciatum in the Florida Keys. Mar Ecol Prog Ser. 308:1-15. http://dx.doi.org/10.3354/meps308001

Tapia F, Pineda J, Ocampo-Torres F, Fuchs H, Parnell E, Montero P, Ramos S. 2004. Highfrequency observations of wind-forced onshore transport at a coastal site in Baja California. Cont Shelf Res. 24:1573-1585. http://dx.doi.org/10.1016/j.csr.2004.03.013

Thiyagarajan V, Harder T, Qian P-Y. 2002. Effect of physiological condition and laboratorymimcked seasonal conditions on the metamorphic successes of Balanus amphitrite Darwin (Cirripedia; Thoracica). J Exp Mar Biol Ecol. 274:65-74. http://dx.doi.org/10.1016/S00220981(02)00182-X

Thiyagarajan V, Harder T, Qian P-Y. 2003. Combined effects of temperature and salinity on larval development and attachment of the subtidal barnacle Balanus trigonus Darwin. Exp Mar Biol Ecol. 287:223-236. http://dx.doi.org/10.1016/50022-0981(02)00570-1

West RC. 1956. Mangrove swamps of the Pacific Coast of Colombia. A Assoc Am Geog. 46:98121.

White BL, Pineda J, Starczak VR. 2010. Larval transport by tidal salinity fronts in a tropical mangrove-fringed estuary. Eos Transactions, AGU Ocean Sci Meet Suppl, Abstract IT43B-07 91. 
Wolanski E, Ridd PV. 1986. Tidal mixing and trapping in mangrove swamps. Estuar Coast Shelf Sci. 23:759-771. http://dx.doi.org/10.1016/0272-7714(86)90073-9

Date Submitted: 19 March, 2010.

DAte ACCEPTED: 13 January, 2011.

Available Online: 16 March, 2011.

Addresses: (VS, JG, JP) Biology Department, Woods Hole Oceanographic Institution, Woods Hole, Massachussetts 02543. (PPB) Departamento de Oceanografía Física, Centro de Investigación Científica y de Educación Superior de Ensenada, Km 107 Carretera TijuanaEnsenada, Ensenada, BC 22860, Mexico. (HEL) $602640^{\text {th }}$ Ave NE, Seattle, Washington 98115. Corresponding Authors: (VS)E-mail: <vstarczak@whoi.edu>. (PPB)E-mail: <brunius@ cicese.mx>. (JP) E-mail: <jpineda@whoi.edu>.

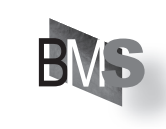

